\title{
Short-term Versus Continuous Chisel and No-till Effects on Soil Carbon and Nitrogen
}

\author{
Rex A. Omonode, Anita Gal, Diane E. Stott, T. Scott Abney, and Tony J. Vyn*
}

\begin{abstract}
For various reasons, North American crop farmers are more likely to practice limited-duration no-till than continuous no-till (NT). Little is known about effects of short-term no-till (ST-NT) on organic C and total $\mathrm{N}$ relative to $\mathrm{NT}$ and conventional-till systems. A field experiment was initiated in 1980 to study the effects of NT, chisel plow (CP), and moldboard plow in continuous corn (CC; Zeamays L.) and soybean (Glycinemax. L.)-corn (SC) rotations on dark prairie soil. In 1996, the moldboard treatments were split into a ST-NT subplot and an intermittently chisel-plowed (STI-CP) subplot that was chiseled only before corn. In 2003, soil samples were taken incrementally to the 1.0-m depth from NT, CP, ST-NT, and STI-CP plots. Soil $\mathrm{C}$ and $\mathrm{N}$ accumulation was unaffected by rotation system at any depth interval. Tillage treatments significantly affected soil $C$ and $N$ concentrations only in the upper $50 \mathrm{~cm}$. On an equivalent soil mass basis, $C$ storage to $1.0 \mathrm{~m}$ after 24 yr totaled $151 \mathrm{Mg} \mathrm{ha}^{-1}$ in continuous NT, but just $108 \mathrm{Mg} \mathrm{ha}^{-1}$ in continuous CP. Short-term no-till and STI-CP systems resulted in 26 and $21 \mathrm{Mg} \mathrm{ha}^{-1}$, respectively, more soil $\mathrm{C}$ than $\mathrm{CP}$. Total $\mathrm{N}$ storage was similar for NT and ST-NT systems, but was significantly lower (4 $\mathrm{Mg} \mathrm{ha}^{-1}$ less) with CP. Our results suggest that the combination of moldboard plowing (17 yr) followed by short-term (6-7 yr) no-till or intermittent chisel was generally superior to continuous chisel plowing (24 yr) in soil $\mathrm{C}$ and $\mathrm{N}$ contents.
\end{abstract}

$\mathrm{B}$ ENEFits ASSOCIATED with long-term NT for soil organic $\mathrm{C}$ sequestration and total $\mathrm{N}$ accumulation can be substantial (Dick et al., 1989). Several studies have shown that conservation tillage (i.e., residue from previous crops cover at least $30 \%$ of the soil surface after planting) practiced for extended periods of time, increased soil organic $\mathrm{C}$ and $\mathrm{N}$ content of the surface soil (Allmaras et al., 2000; Eghball et al., 1994; Dick, 1983). However, the benefits of no-till vary with such factors as location (McConkey et al., 2003), landscape position (VandenBygaart et al., 2002), depth of sampling (Potter et al., 1998, 1997; Karlen et al., 1994; Balesdent et al., 1990), or cropping systems (Diekow et al., 2004; Duiker and Lal, 1999; Lal et al., 1994).

No-till practices have been reported to maintain and sometimes enhance soil aggregation (Mahboubi and Lal, 1998), conserve soil moisture and increase infiltration in the presence of surface mulches (Diaz-Zorita et al., 2004; Unger and Jones, 1994; Mahboubi et al., 1993). In 2004, about $41 \%$ of all croplands in the USA were under conservation tillage systems. Of the $41 \%$ of

R.A. Omonode, A. Gal, and T.J. Vyn, Dep. of Agronomy, Purdue Univ., Lilly Hall of Life Sciences, West Lafayette, IN 47907; D.E. Stott, USDA-ARS, National Soil Erosion Research Lab., West Lafayette, IN 47907; T.S. Abney, Dep. of Botany and Plant Pathology, Purdue Univ., Lilly Hall of Life Sciences, West Lafayette, In 47907. Received 19 Mar. 2005.*Corresponding author (tvyn@purdue.edu).

Published in Soil Sci. Soc. Am. J. 70:419-425 (2006).

Soil \& Water Management \& Conservation

doi:10.2136/sssaj2005.0083

(c) Soil Science Society of America

677 S. Segoe Rd., Madison, WI 53711 USA croplands under conservation tillage, no-till accounted for $23 \%$ or 62.4 million acres, up from $20 \%$ in 2002, and $17.5 \%$ in 2000 (CTIC, 2004).

Research reports about no-till's benefit to soil properties are not unanimous. Powlson and Jenkinson (1981) found no significant differences in organic $\mathrm{C}$ and total $\mathrm{N}$ between no-till and moldboard plow in experiments conducted for 5 to $10 \mathrm{yr}$. Campbell et al. (1996) reported that increases in organic $\mathrm{C}$ storage in the 0 - to $15-\mathrm{cm}$ soil depth were just 0 to $3 \mathrm{Mg} \mathrm{ha}^{-1} 11$ to $12 \mathrm{yr}$ after conversion from conventional to no-tillage management systems. Long-term no-till may also result in increased bulk density (Chen et al., 1998) and higher incidence of weed infestations (Kettler et al., 2000). In the fields used for this study, Schreiber (1992) reported a significantly higher number of giant foxtail (Setaria faberi) seeds in the $0-$ to $2.5-\mathrm{cm}$ soil depth when tillage was reduced from conventional moldboard plowing to chiseling and to notill for a 10 -yr period.

Although no-till management is widely adopted in the Eastern Corn Belt, and in spite of reports of favorable economic returns of no-till especially for soybean (Glycine $\max$ L.) production (Yin and Al-Kaisi, 2004), cropland in long-term NT is limited (Hill, 1998). In practice, farmers often plow their no-till fields, albeit intermittently, before a specific crop in rotation or to correct perceived compaction, pest, or soil management problems that may result from long-term no-till (Pierce et al., 1994). Little is known about the short-term changes during transition between these management systems, and about the persistence of soil organic $\mathrm{C}$ when no-till fields are plowed intermittently (VandenBygaart and Kay, 2004; McCarty et al., 1998).

In the first year following a one-time moldboard plowing of prior no-till soils, Pierce et al. (1994) reported that plowing did not eliminate stratification of chemical properties, but significantly reduced soil organic $\mathrm{C}$ and total $\mathrm{N}$ in the surface $20 \mathrm{~cm}$. However, 4 to $5 \mathrm{yr}$ after plowing differences in $\mathrm{C}$ and $\mathrm{N}$ contents between the plowed and no-till were small and significant only at the $0-$ to $5-\mathrm{cm}$ depth interval. Similarly, in southern Ontario, Canada, VandenBygaart and Kay (2004) found that a one-time $20-\mathrm{cm}$ depth moldboard plowing of a 22-yr NT field significantly reduced soil organic $\mathrm{C}$ concentrations in the surface $5 \mathrm{~cm}$, but the reduction in SOC was countered by an increase at the lower depths 18 mo after plowing. Therefore, when calculated on an equivalent mass basis beyond the plow depth, there was no significant change in soil organic $\mathrm{C} 18$ mo after plowing in 3 of 4 soil types. In Kentucky, Diaz-Zorita et al. (2004) found no significant differences in organic $\mathrm{C}$ and total $\mathrm{N}$ contents

\footnotetext{
Abbreviations: CC, continuous corn; CP, continuous chisel plow; NT, continuous no-till; SC, soybean-corn rotations; STI-CP, short-term intermittent chisel plow; ST-NT, short-term no-till.
} 
between no-till and intermittently chisel-plowed soils 8 to 20 mo after plowing.

Rotational tillage is used on about $40 \%$ of the agricultural fields in Indiana; typically, no-till soybean is followed by intensive tillage for corn. However, there has been little research designed to study the short and/or long-term intermittent tillage effects on organic $\mathrm{C}$ storage in the Midwest Corn Belt or elsewhere. In addition, these studies were limited mostly to a one-time plowing event and data were collected only to the surface $30 \mathrm{~cm}$ (DiazZorita et al., 2004; Pierce et al., 1994). Subsoil layers can function as a $\mathrm{C}$ sink depending on the cropping system (Swift, 2001) and the necessity to consider soil layers below the plow depth $(30 \mathrm{~cm})$ in the assessment of management impact (intermittent tillage inclusive) on soil organic $\mathrm{C}$ has been emphasized by Mikhailova et al. (2000) and supported by Diekow et al. (2004). The objectives of this study therefore were to (i) determine the effects of various short-term intermittent tillage systems on organic $\mathrm{C}$ and total $\mathrm{N}$ relative to NT and chisel plow systems, and (ii) evaluate the effects of these tillage systems and their interaction with crop rotation on organic $\mathrm{C}$ and total $\mathrm{N}$ distribution in the soil profile.

\section{MATERIALS AND METHODS}

\section{Site Description and Experimental Design}

This study was performed at the Purdue University Agronomy Center for Research and Education near West Lafayette, IN. The soil is a poorly drained Chalmers silty clay loam (finesilty, mixed, superactive, mesic Typic Endoaquoll), but with drainage tiles installed at $30 \mathrm{~m}$ spacing.

The experiment was established in 1980 with various tillage, crop rotation, weed management, and cover crop treatments in plots measuring $15 \mathrm{~m}$ wide and $90 \mathrm{~m}$ long. The experimental design was a split-split plot with four replications. At the time of establishment in 1980 whole plots were factorial combinations of crop rotations and tillage and herbicide treatments randomized in each rotation. Rotations consisted of CC ( Zea mays L.), continuous soybean, a 2-yr rotation of corn-soybean, and a 3-yr rotation of corn-soybean-wheat (Triticum aestivum L.). The tillage treatments were moldboard plow, chisel plow, and no-till. Fall moldboard and fall chisel plowing were followed by secondary spring tillage utilizing a field cultivator for final seedbed preparation. In the no-till system the crop was seeded directly into the previous crop residue with no soil preparation. This system left most of the cover of the previous crop residue on the surface. The whole plots and subplots (three weed management treatments) have been described in more detail by Schreiber (1992).

In the fall of 1996, the weed management and cover crop treatments were discontinued and the experiment was redesigned to simulate tillage activity common to corn-soybean rotation systems in the Midwest. Emphasis was focused on rotation and tillage treatments whereby the tillage treatments were randomized in rotations in a split-plot design replicated three times. Here the moldboard plowed plots in both the CC and SC rotations were converted to short-term intermittent tillage systems. The plots were divided into two subplots where one subplot was chisel plowed before corn (every year or every $2 \mathrm{yr}$ depending on the rotation system) but the other subplot was left untilled for all crops in sequence (Table 1). This resulted in four tillage treatments namely: continuous notill (NT), continuous chisel plow (CP), short-term no-till (ST-
Table 1. Abbreviations and description of the tillage and rotation treatments used in this study.

\begin{tabular}{|c|c|c|}
\hline Abbreviation & Rotation & Tillage description \\
\hline NT & $\begin{array}{l}\text { Corn-corn (CC)/ } \\
\text { soybean-corn (SC) }\end{array}$ & $\begin{array}{l}\text { Continuous no-till from } 1980 \\
\text { until } 2003 \text { ( } 24 \text { yr) }\end{array}$ \\
\hline CP & CC/Ś & $\begin{array}{l}\text { Continuous chisel plow from } \\
1980 \text { until } 2003 \text { ( } 24 \text { yr) }\end{array}$ \\
\hline ST-NT & CC/SC & $\begin{array}{l}\text { Moldboard plow in } 1980-1996 \\
(17 \text { yr), chisel plow in } 1997 \\
(1 \mathrm{yr}), \text { no-till in } 1998-2003 \\
(6 \mathrm{yr})\end{array}$ \\
\hline STI-CP $\dagger$ & $\mathbf{C C} / \mathbf{S C}$ & $\begin{array}{l}\text { Moldboard plow in 1980-1996 } \\
(17 \text { yr }) \text {, chisel plow in } \\
1997-2003 \text { ( } 7 \text { yr })\end{array}$ \\
\hline
\end{tabular}

$\dagger$ Intermittent chisel plow was applied annually for $\mathrm{CC}$ rotation, and in alternate years $(1996,1998,2000$, and 2002) for the $S C$ rotation before the respective corn crops.

NT), and short-term intermittent chisel plow (STI-CP). Thus, for this experiment a split-plot design with three replications in a randomized complete block layout was utilized. Whole plots were crop rotation and tillage treatments were randomized in each rotation.

\section{Soil Sampling}

Soil samples were taken from selected subplots that had the highest rates of herbicides applied for weed control (19801996) and also had no cover crops (1997-2003). Samples from the tillage treatments in both the CC and SC rotations were obtained mainly in the fall of 2003, after corn harvest but before primary tillage. A few deep soil cores for ST-NT in CC rotation had to be taken in the spring of 2004 because the soil was too wet at the time of sampling in the fall of 2003. This was done after the soil was considered settled and before secondary tillage operations. Samples were taken from three sampling positions per plot using a hydraulically driven probe mounted on a truck. At each sampling position, three cores were taken to 1-m depth at 0- to 5-, 5- to 15-, 15- to 30-, 30- to $50-, 50-$ to $75-$, and $75-$ to $100-\mathrm{cm}$ intervals and made into composites. The samples were air-dried and plant residues were removed. The soil was coarsely ground with a soil hammer mill, sieved through a 2-mm sieve, and then finely ground using a Dyno-Crush 2 Grinder (Customs Laboratory Equipments, Inc., FL).

\section{Laboratory Analyses}

\section{Bulk Density and Fertility Variables}

Bulk density determination for surface samples $(0-5,5-15$, and $15-30 \mathrm{~cm}$ ) was performed by the core method on additional samples (three samples per plot) collected with a doublecylinder, hammer-driven core sampler. These samples were collected in the spring of 2004 before secondary tillage, but after primary tillage operations (for the continuous $\mathrm{CP}$ and STI-CP in $\mathrm{CC}$ rotation) in the fall of 2003. For the deeper depth soil samples $(30-50,50-75,75-100 \mathrm{~cm})$ bulk density was determined using samples collected by the probe truck after determining their moisture contents. Selected fertility parameters ( $\mathrm{pH}$, phosphorus, potassium, and cation exchange capacity) were determined on subsamples taken from the air-dried and sieved samples in a commercial laboratory (A \& L Great Lakes Laboratories Inc. Fort Wayne, IN) after extraction with the Mehlich-3 extractant (Mehlich, 1984).

\section{Organic Carbon and Total Nitrogen}

Organic $\mathrm{C}$ and total $\mathrm{N}$ concentrations were determined by dry combustion analysis using Leco CHN 2000 (Leco Corp., 
St. Joseph, MI). However, because the soils were formed from calcareous parent materials, samples from the 50- to 75- and 75- to 100-cm depths were pretreated with excess amount of $0.1 \mathrm{M} \mathrm{HCl}$ to remove inorganic $\mathrm{C}$ before analysis. Since there was no recent lime application on these plots and soil $\mathrm{pH}$ was generally below 7.0, total $\mathrm{C}$ content was considered equal to the organic $\mathrm{C}$ content. Organic $\mathrm{C}$ and total $\mathrm{N}$ were expressed both as concentration $\left(\mathrm{g} \mathrm{C} \mathrm{kg}^{-1}\right.$ soil) and mass $\left(\mathrm{Mg} \mathrm{C}^{-1}\right)$ to a fixed depth increment. Ratios of $\mathrm{C}$ to $\mathrm{N}$ at individual depth increments were calculated on an elemental atomic weight basis.

Treatment effects on soil $\mathrm{C}$ and $\mathrm{N}$ storage were compared based on values expressed in equivalent mass because the conventional methods (product of the concentration, soil bulk density, and soil layer thickness) are believed to be inadequate as they do not take into full consideration the influence of soil mass on nutrient storage (Ellert and Bettany, 1995; Hooker et al., 2005). On the other hand, the equivalent mass procedures have been shown to recover greater $\mathrm{C}$ mass and are more sensitive in detecting differences of $\mathrm{C}$ mass among treatments (Ellert and Bettany, 1995; Ellert et al., 2002). Briefly, equivalent mass of $\mathrm{C}$ and $\mathrm{N}$ was determined first by multiplying concentrations in each depth increment at 0 to 5,5 to 15,15 to 30,30 to 50,50 to 75 , and 75 to $100 \mathrm{~cm}$ by the corresponding bulk density and depth thickness values as shown in Eq. [1]:

$M_{\text {element }}=\operatorname{conc} \cdot \rho_{\mathrm{b}} \cdot T \cdot 10000 \mathrm{~m}^{2} \mathrm{ha}^{-1} \cdot 0.001 \mathrm{Mgkg}^{-1}[1]$

where $M_{\text {element }}=\mathrm{C}$ or $\mathrm{N}$ mass per unit area $\left(\mathrm{Mg} \mathrm{ha}^{-1}\right)$; conc $=$ nutrient concentration $\left(\mathrm{kg} \mathrm{Mg}^{-1}\right) ; \rho_{\mathrm{b}}=$ bulk density $\left(\mathrm{Mg} \mathrm{m}^{-3}\right)$; and $T=$ thickness of soil layer (m). Total $\mathrm{C}$ and $\mathrm{N}$ mass was then estimated by summing across the depth intervals to a 1-m depth. Next, variable amounts of additional soil thickness (and associated soil mass) were added to the less dense treatments from the deeper depths to bring all samples to an equivalent mass by scaling up or down against a designated equivalent soil mass. Depending on the objectives, the choice of equivalent soil mass may vary from the heaviest (Ellert and Bettany, 1995) to the smallest soil mass (Wander et al., 1998), and to soil mass averaged across treatments in multiple locations (Zan et al., 2001).

Initial analysis of the data showed that bulk density was not significantly different among the treatments; therefore tillage treatments were averaged over rotations and used for further analysis. Although bulk density values were not significantly different, the equivalent mass procedure was still adopted as the basis for $\mathrm{C}$ sequestration comparison among treatments and the heaviest soil mass was designated the equivalent mass to ensure maximum recovery of organic $\mathrm{C}$ mass stored under the treatments. After averaging over rotations, the heaviest soil mass was found to be $15418 \mathrm{Mg} \mathrm{ha}^{-1}$ (before averaging, the heaviest mass was $15586 \mathrm{Mg} \mathrm{ha}^{-1}$ under $\mathrm{CP}$ in SC rotation) recovered under ST-NT and was designated the equivalent mass. The additional thickness of soil needed to bring all samples to equivalent mass was then calculated as described in Eq. [2]:

$$
T_{\text {add }}=\frac{\left(M_{\text {soil }, \text { equiv }}-M_{\text {soil,adj }}\right) 0.0001 \text { ha }^{-2}}{\rho_{\text {b subsurface }}}
$$

where: $T_{\text {add }}=$ additional thickness of subsurface layer required to attain the equivalent soil mass (m); $M_{\text {soil, equiv }}=$ reference equivalent soil mass ( $\left.15418 \mathrm{Mg} \mathrm{ha}^{-1}\right) ; M_{\text {soil, adj }}=$ soil mass to be adjusted (soil mass of the $75-$ to $100-\mathrm{cm}$ depth interval); and $\rho_{\mathrm{b} \text { subsurface }}=$ bulk density of subsurface soil beneath the depth interval to be adjusted. Here subsurface bulk density $\left(\rho_{\mathrm{b} \text { subsurface }}\right)$ was assumed to be similar to that of the 75- to $100-\mathrm{cm}$ depth interval; therefore $\rho_{\mathrm{b}}$ subsurface took on the bulk density values of the $75-$ to $100-\mathrm{cm}$ depth interval. This resulted in added soil thickness that ranged from $0.0002 \mathrm{~m}$ in STI-CP to $0.0162 \mathrm{~m}$ in NT. Lastly, the bulk density and concentrations of the 75- to $100-\mathrm{cm}$ depths were then used to estimate $\mathrm{C}$ and $\mathrm{N}$ mass in the additional thickness for the NT, STI-CP, and CP treatments and these were added to the $\mathrm{C}$ and $\mathrm{N}$ mass of the $75-$ to $100-\mathrm{cm}$ interval and, subsequently, to the total mass recovered to a $1.0-\mathrm{m}$ depth. Further information about equivalent mass determination can be found in Ellert and Bettany (1995) and Ellert et al. (2002).

\section{Statistical Analysis}

Statistical analysis of the data was performed using the General Linear Model in SAS (SAS Institute, 2002) with rotation as main plots and tillage as subplots. First, the data was analyzed separately to determine if significant differences existed between the yearly and alternate-year chisel plow treatments (recall that STI-CP was applied every year for CC and every alternate year for SC rotation). Next, the data was further analyzed to determine if a significant difference existed between the rotation systems (rotation effect). These analyses indicated there was no significant difference between STI-CP applied every year or every alternate year, and between rotations. Thereafter, rotation effects were combined by averaging tillage treatment effects by depth intervals over rotations and further analyzed simply as NT, ST-NT, STI-CP, and CP treatments. Mass of $\mathrm{C}$ and $\mathrm{N}$ (on equivalent mass basis) stored in the surface $100 \mathrm{~cm}$ for each tillage treatment was calculated by summing $\mathrm{C}$ and $\mathrm{N}$ in each depth interval to a 1-m soil depth. The data were analyzed by analysis of variance (ANOVA) using the PROC GLM procedure. Treatment means were separated using least significant difference (LSD) and the effects of tillage on $\mathrm{C}$ and $\mathrm{N}$ sequestration and their vertical distribution was evaluated at the $5 \%$ level of probability $(\alpha=0.05)$.

\section{RESULTS AND DISCUSSION}

\section{Soil Fertility Characteristics, Organic Carbon, and Total Nitrogen Concentrations}

Selected soil fertility characteristics in the 0- to 5-, 5to $15-$, and $15-$ to $30-\mathrm{cm}$ depth intervals are shown in Table 2. As anticipated, available $P$ and exchangeable $\mathrm{K}$ decreased with increasing soil depth (not all depths are shown). However, the decrease was rapid between the 0 - to 5- and 5- to $15-\mathrm{cm}$ depth intervals, and more

Table 2. Measured soil fertility characteristics in continuous notill (NT), short-term no-till (ST-NT), intermittent chisel plow (STI-CP), and continuous chisel plow (CP) in the 0- to 5-, 5- to 15-, and 15- to 30-cm depth increments.

\begin{tabular}{|c|c|c|c|c|c|}
\hline \multirow[b]{2}{*}{ Treatment } & \multicolumn{5}{|c|}{ Soil fertility characteristics } \\
\hline & Depth & pH & $\mathbf{P}$ & $\mathbf{K}$ & CEC \\
\hline & \multicolumn{2}{|l|}{ cm } & \multicolumn{2}{|c|}{$\mathbf{m g ~ k g} \mathbf{~}^{-1}$} & $\mathrm{Cmol} \mathrm{kg}^{-1}$ \\
\hline \multirow[t]{3}{*}{ NT } & $0-5$ & 6.2 & $65^{*}$ & 253 & 19.8 \\
\hline & 5-15 & 6.6 & 36 & 136 & 19.4 \\
\hline & 15-30 & 6.0 & 18 & 117 & 20.0 \\
\hline \multirow[t]{3}{*}{ ST-NT } & 0-5 & 6.7 & 48 & 232 & 19.6 \\
\hline & 5-15 & 6.1 & 33 & 135 & 21.2 \\
\hline & 15-30 & 6.3 & 16 & 123 & 20.8 \\
\hline \multirow[t]{3}{*}{ STI-CP } & $0-5$ & 7.1 & 41 & 257 & 18.5 \\
\hline & $5-15$ & 6.7 & 25 & 154 & 19.3 \\
\hline & 15-30 & 6.8 & 13 & 109 & 20.9 \\
\hline \multirow[t]{3}{*}{$\mathbf{C P}$} & $0-5$ & 6.9 & 32 & 216 & $15.7 *$ \\
\hline & 5-15 & 6.4 & 26 & 141 & 16.9 \\
\hline & 15-30 & 6.4 & 10 & 126 & 17.9* \\
\hline
\end{tabular}

* Significantly different from other tillage treatments at the alpha $=0.05$ at the specified depth interval. 
pronounced for available $\mathrm{P}$ than for exchangeable $\mathrm{K}$ beyond these depth intervals. In the 0 - to 5-cm depth interval, NT significantly increased available P concentration more than ST-NT, STI-CP, and CP. In general, the magnitude of available $\mathrm{P}$, exchangeable $\mathrm{K}$, and $\mathrm{CEC}$ were in the order: NT $>$ ST-NT $>$ STI-CP $>$ CP. However, both $\mathrm{P}$ and $\mathrm{K}$ concentrations were well above the accepted critical levels recommended for these soils (Vitosh et al., 1995); therefore, these nutrients were not expected to impair relative crop biomass production in any tillage system.

The general effects of tillage, rotation, and their interaction on soil $\mathrm{C}$ and $\mathrm{N}$ (on concentration and mass bases) are presented in Table 3. Tillage effects were significant for $\mathrm{C}$ and $\mathrm{N}$ mostly in the 0 - to 5-, 5- to $15-, 15$ - to $30-$ and $30-$ to $50-\mathrm{cm}$ depth intervals, while significant rotation effects were restricted to total $\mathrm{N}$ and only in the 50 - to 75- and 75- to $100-\mathrm{cm}$ depth increments. In general, there was no tillage by rotation interaction effects except for organic $\mathrm{C}$ in the 5 - to $15-\mathrm{cm}$ depth (on concentration basis) and in the 15- to $30-\mathrm{cm}$ depth interval (on mass basis).

Concentrations of $\mathrm{C}$ and $\mathrm{N}$ were slightly higher in $\mathrm{CC}$ than in SC rotation in the 0- to 5-cm interval (Table 4). In general, soil $\mathrm{C}$ concentrations were not significantly altered by rotations; in that respect our results were similar to those of Yang and Kay (2001). However, CC significantly increased $\mathrm{N}$ relative to $\mathrm{SC}$ rotation in the 50- to 75 - and 75- to $100-\mathrm{cm}$ depths. Similarly, significant rotation differences in the $\mathrm{C} / \mathrm{N}$ ratios were observed only at the 50- to 75- and 75- to 100-cm depth intervals.

The quantity of corn residues returned to soil is considered to be a major factor affecting the resultant soil $\mathrm{C}$ concentration (Barber, 1979). Therefore, $\mathrm{C}$ was expected to be higher in $\mathrm{CC}$ relative to $\mathrm{SC}$ rotation due to the

Table 3. Statistical analyses of tillage, rotation, and tillage $\times$ rotation interaction effects on organic $C$ and total $N$ based on concentration and mass at various depth increments.

\begin{tabular}{|c|c|c|c|c|}
\hline \multirow[b]{2}{*}{ Source } & \multicolumn{4}{|c|}{$\boldsymbol{P}>\mathbf{F}$} \\
\hline & Organic C & Total N & Organic C & Total N \\
\hline & \multicolumn{2}{|c|}{ (Concentration basis) } & \multicolumn{2}{|c|}{ (Mass basis) } \\
\hline $0-5 \mathrm{~cm}$ & & & & \\
\hline Rotation & 0.4450 & 0.2675 & 0.5839 & 0.8631 \\
\hline Tillage & 0.0033 & 0.0270 & 0.0544 & 0.0590 \\
\hline $\begin{array}{l}\text { Rotation } \times \text { tillage } \\
5-15 \mathrm{~cm}\end{array}$ & 0.8822 & 0.9845 & 0.9618 & 0.6224 \\
\hline Rotation & 0.1724 & 0.8302 & 0.8799 & 0.7619 \\
\hline Tillage & 0.0563 & 0.6372 & 0.3712 & 0.3063 \\
\hline $\begin{array}{l}\text { Rotation } \times \text { tillage } \\
15-30 \mathrm{~cm}\end{array}$ & 0.0158 & 0.8545 & 0.5833 & 0.8962 \\
\hline Rotation & 0.3205 & 0.4452 & 0.3788 & 0.6082 \\
\hline Tillage & 0.0075 & 0.0591 & 0.0064 & 0.1645 \\
\hline $\begin{array}{l}\text { Rotation } \times \text { tillage } \\
30-50 \mathrm{~cm}\end{array}$ & 0.0985 & 0.7774 & 0.0528 & 0.6330 \\
\hline Rotation & 0.4137 & 0.7892 & 0.9410 & 0.9884 \\
\hline Tillage & 0.0018 & 0.0336 & 0.0341 & 0.0844 \\
\hline $\begin{array}{l}\text { Rotation } \times \text { tillage } \\
50-75 \mathrm{~cm}\end{array}$ & 0.1686 & 0.4941 & 0.8021 & 0.7759 \\
\hline Rotation & 0.8833 & 0.0088 & 0.6559 & 0.0015 \\
\hline Tillage & 0.1341 & 0.2474 & 0.4076 & 0.1329 \\
\hline $\begin{array}{l}\text { Rotation } \times \text { tillage } \\
75-100 \mathrm{~cm}\end{array}$ & 0.9207 & $\mathbf{0 . 3 3 9 7}$ & 0.9946 & 0.0943 \\
\hline Rotation & 0.4667 & 0.0076 & 0.4042 & 0.0007 \\
\hline Tillage & 0.3904 & 0.2699 & 0.3144 & 0.1546 \\
\hline Rotation $\times$ tillage & 0.2129 & 0.3174 & 0.3861 & 0.2417 \\
\hline
\end{tabular}

Table 4. Rotation effects on $\mathrm{C}$ and $\mathrm{N}$ concentrations, and $\mathrm{C} / \mathrm{N}$ ratios in different depth increments to $1-m$ depth.

\begin{tabular}{|c|c|c|c|c|c|c|}
\hline \multirow[b]{2}{*}{ Rotation } & \multicolumn{6}{|c|}{ Soil depth, cm } \\
\hline & $0-5$ & 5-15 & 15-30 & 30-50 & $50-75$ & 75-100 \\
\hline \multicolumn{7}{|c|}{ Organic $\mathrm{C}, \mathrm{g} \mathrm{kg}^{-1}$} \\
\hline Corn-corn & $29.5 \mathrm{a}$ & $21.5 \mathrm{a}$ & 15.5a & $7.5 \mathrm{a}$ & 3.7a & $2.8 \mathrm{a}$ \\
\hline Bean-corn & $27.8 \mathrm{a}$ & $24.0 \mathrm{a}$ & 17.0a & 8.1a & 3.8a & $2.6 \mathrm{a}$ \\
\hline \multicolumn{7}{|c|}{ Total N, $\mathbf{g ~ k g}^{-1}$} \\
\hline Corn-corn & 2.2a & $1.7 \mathbf{a}$ & $1.0 \mathrm{a}$ & 3.9a & $0.2 \mathrm{a}$ & $0.1 \mathrm{a}$ \\
\hline Bean-corn & 1.9a & $1.6 a$ & 1.1a & 4.1a & $0.1 b$ & $0.02 b$ \\
\hline \multicolumn{7}{|c|}{$\mathrm{C} / \mathrm{N}$ ratio } \\
\hline Corn-corn & 16.4a & 15.6a & 18.3a & 28.3a & 24.30a & 37.5a \\
\hline Bean-corn & 17.4a & $16.7 \mathbf{a}$ & 18.3a & $22.6 a$ & $55.5 b$ & $120.0 b$ \\
\hline
\end{tabular}

Rotations that are followed by the same letters within depth intervals are not significantly different at $P=0.05$.

relatively greater amounts of biomass expected to be produced and returned annually to soil. However, higher soil $\mathrm{C}$ and $\mathrm{N}$ due to higher residue input of legume-based cropping systems relative to cereal-based cropping systems have been reported (Diekow et al., 2004; Wilhelm and Wortmann, 2004). Similarly, Wilhelm and Wortmann (2004) suggested that corn stover additions were higher for the corn year in the rotation cycle versus the corresponding $\mathrm{CC}$ treatments. The absence of significant differences in $\mathrm{C}$ and $\mathrm{N}$ concentrations of $\mathrm{CC}$ versus cornsoybean rotation in our research was probably due to higher corn residues produced in the corn year of the corn-soybean rotation relative to smaller quantities in CC. Furthermore, the amount of crop residues returned to soils in general may be proportional to grain yields (Raimbault and Vyn, 1991). Greater corn grain yields (and, by implication, greater biomass) in rotation versus continuous cropping have been reported in rotation experiments on a similar soil in Indiana (West et al., 1996), although it is of interest that Schreiber (1992) reported no significant differences in corn yield among CC, SC, and soybean-wheat-corn rotations for these fields between 1982 and 1990.

Tillage system effects on $\mathrm{C}$ and $\mathrm{N}$ concentrations are shown in Table 5. Carbon and $\mathrm{N}$ concentrations were generally higher in the top 0 - to 5-cm depth interval, and generally decreased with depth in all tillage systems. However, the rate of decline was highest for NT relative to ST-NT and STI-CP, and was least for CP, which was an indication of reduced stratification due to tillage. Among tillage systems, the magnitude of $\mathrm{C}$ and $\mathrm{N}$

Table 5. Effects of continuous no-till (NT), short-term no-till (ST-NT), intermittent chisel plow (STI-CP), and continuous chisel plow (CP) on organic $\mathrm{C}$ and total $\mathrm{N}$ concentrations in different depth increments to 1-m depth.

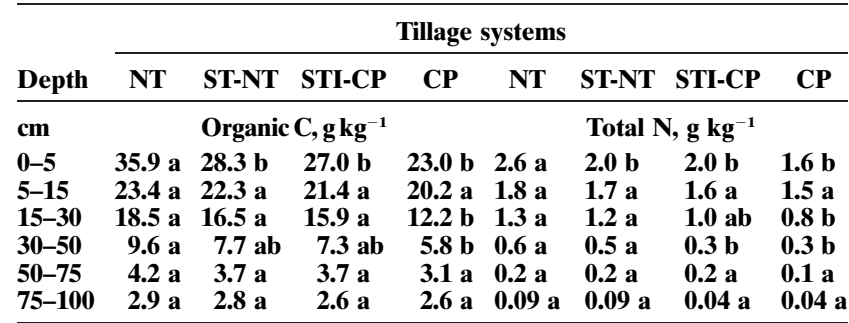

Tillage treatments that are followed by the same letters within depth increments are not significantly different at $P=0.05$. 
Table 6. Effects of continuous no-till (NT), short-term no-till (STNT), intermittent chisel plow (STI-CP), and continuous chisel plow (CP) on soil bulk density in different depth increments.

\begin{tabular}{|c|c|c|c|c|}
\hline \multirow[b]{2}{*}{ Depth, cm } & \multicolumn{4}{|c|}{ Tillage treatment } \\
\hline & NT & ST-NT & STI-CP & $\mathbf{C P}$ \\
\hline & \multicolumn{4}{|c|}{ Bulk density $\left(\mathrm{Mg} \mathrm{m}^{-3}\right)$} \\
\hline $0-5$ & 1.12 & 1.18 & 1.17 & 1.11 \\
\hline $5-15$ & 1.42 & 1.40 & 1.38 & 1.36 \\
\hline 15-30 & 1.43 & 1.43 & 1.47 & 1.43 \\
\hline $30-50$ & 1.53 & 1.56 & 1.55 & 1.54 \\
\hline $50-75$ & 1.57 & 1.60 & 1.64 & 1.63 \\
\hline 75-100 & 1.62 & 1.67 & 1.61 & 1.68 \\
\hline
\end{tabular}

concentration was in the order: NT $>$ ST-NT $>$ STI-CP $>$ $\mathrm{CP}$. Continuous no-till consistently increased $\mathrm{C}$ concentrations more than $\mathrm{CP}(P<0.024)$ in all but the $75-$ to 100-cm depth interval, and increased C more than ST-NT and STI-CP in the top 50-cm depths. In contrast, NT significantly increased $\mathrm{N}$ concentrations relative to STI$\mathrm{CP}$ and $\mathrm{CP}$ only in the $0-$ to $5-$ and $30-$ to $50-\mathrm{cm}$ intervals. Similarly, soil $\mathrm{C}$ and $\mathrm{N}$ concentrations were slightly higher in ST-NT and STI-CP than CP at all depth intervals. Consistent with Reicosky (1997) and Reicosky et al. (1997), the higher C concentrations in NT, ST-NT, and STI-CP systems over CP suggested that more crop residue was proportionately transformed into soil $\mathrm{C}$ when soil was not tilled or that the minimal soil disturbance in no-till reduced mineralization rates and loss of organic $\mathrm{C}$.

\section{Bulk Density, Organic Carbon, and Nitrogen Mass}

Bulk density values were lowest near the surface but generally increased as soil depth increased (Table 6), and ranged from 1.11 to $1.18 \mathrm{Mg} \mathrm{m}^{-3}$ in the 0 - to $5-\mathrm{m}$ depth interval. Tillage effects were not consistent and were generally not significant at any depth interval. However, bulk density for CP was smaller than for NT in the top 30-cm depth, which was due to the probable loosening effect of chisel plowing. Inconsistent effects of tillage on bulk density have been widely reported in the literature. For example, Wander et al. (1998) and Pierce et al. (1994) reported greater bulk density under no-till relative to conventional tillage. In contrast, Diaz-Zorita et al. (2004) found no significant difference in bulk density of NT and intermittent plowing. Similarly, Yang and Kay (2000) found no difference in bulk density of reduced tillage, chisel, and moldboard plow treatments.
Soil masses to the 1-m depth on a unit area basis were only slightly different among treatments (on average: ST-NT = 15 418; $\mathrm{CP}=15$ 415; STI-CP $=15$ 393; and $\mathrm{NT}=15156 \mathrm{Mg} \mathrm{ha}^{-1}$ ) and organic $\mathrm{C}$ and $\mathrm{N}$ calculated on equivalent soil mass basis to the 1-m depth resulted in an insignificant change relative to the respective masses of $\mathrm{C}$ and $\mathrm{N}$ calculated to a consistent depth basis. However, mass of $\mathrm{C}$ and $\mathrm{N}$ was reported on equivalent mass basis because it reflected more appropriately the management-induced variation in soil mass that was associated with the treatments (Hooker et al., 2005; Ellert et al., 2002).

Most of the soil $\mathrm{C}$ mass was stored in depth intervals between 0 and $50 \mathrm{~cm}$ (Table 7). Soil C storage at greater depths $(75-100 \mathrm{~cm})$ was approximately $11 \mathrm{Mg} \mathrm{ha}^{-1}$; the latter confirms the relative importance of acknowledging the $\mathrm{C}$ sink potential at these deeper depths (Diekow et al., 2004; Swift, 2001). In general, C sequestration was consistently greatest in NT and smallest for $\mathrm{CP}$ at all depth intervals. Averaged to a 1-m depth, the equivalent mass of $\mathrm{C}$ accumulated ranged approximately between 107.8 and $150.5 \mathrm{Mg} \mathrm{ha}^{-1}$ (calculated to fixed depth: $\mathrm{CP}=107.8$ and $\mathrm{NT}=150.4 \mathrm{Mg} \mathrm{ha}^{-1}$ ) and $\mathrm{C}$ mass decreased in the order: NT $>$ ST-NT $>$ STI-CP $>$ CP. Similarly, cumulative $\mathrm{N}$ mass (calculated to 1-m depth) was $6.1,7.5,8.9$, and $9.8 \mathrm{Mg} \mathrm{ha}^{-1}$ respectively, for $\mathrm{CP}$, STI-CP, ST-NT, and NT, respectively.

In general, $\mathrm{C}$ and $\mathrm{N}$ accumulated to the 1-m depth under NT was clearly superior to CP but was not statistically different from ST-NT and STI-CP systems. In similar studies in Kentucky, Diaz-Zorita et al. (2004) found no significant difference in organic $\mathrm{C}$ contents 8 to 20 mo after no-till soils were intermittently plowed. Pierce et al. (1994) and Kettler et al. (2000) reported that a one-time plowing of no-till soils resulted in a redistribution of soil organic $\mathrm{C}$ in the top 15 to $30 \mathrm{~cm}$ but did not result to a significant change in soil organic $\mathrm{C}$ storage 4 to $5 \mathrm{yr}$ after plowing. Pierce et al. (1994) attributed the inability to observe a significant change to annual variability of soil organic $C$ that appeared to override any effects of the single tillage event. VandenBygaart and Kay (2004) also reported that the single moldboard tillage event of a 22-yr no-till field in Southern Ontario homogenized the organic $\mathrm{C}$ through the profile and reduced stratification but resulted in no overall significant change of organic $\mathrm{C}$ within a $50-\mathrm{cm}$ sampling depth, 18 mo after plowing.

Table 7. Organic $\mathrm{C}$ and total $\mathrm{N}$ mass (on equivalent mass basis) as affected by continuous no-till, short-term no-till, intermittent chisel plow, and continuous chisel plow in different depth increments, and averaged to $1 \mathrm{~m}$ depth.

\begin{tabular}{|c|c|c|c|c|c|c|c|c|}
\hline \multirow[b]{2}{*}{ Depth } & \multicolumn{8}{|c|}{ Tillage systems } \\
\hline & NT & ST-NT & STI-CP & $\mathbf{C P}$ & NT & ST-NT & STI-CP & $\mathbf{C P}$ \\
\hline cm & \multicolumn{4}{|c|}{ Organic C $\left(\mathrm{Mg} \mathrm{ha}^{-1}\right)$} & \multicolumn{4}{|c|}{ Total N $\left(\mathrm{Mg} \mathrm{ha}^{-1}\right)$} \\
\hline $0-5$ & 20.1a & 16.7ab & 15.8ab & $12.7 \mathbf{b}$ & $1.4 a$ & 1.2ab & 1.2ab & $0.9 \mathrm{~b}$ \\
\hline $5-15$ & 33.2a & 31.2a & 29.5a & $27.4 a$ & $2.6 a$ & $2.4 a$ & $2.2 \mathrm{a}$ & $2.0 \mathbf{a}$ \\
\hline 15-30 & 39.6a & $35.4 \mathrm{a}$ & 35.1a & $26.2 b$ & $2.8 \mathbf{a}$ & $2.6 a b$ & 2.2ab & $1.7 \mathbf{b}$ \\
\hline 30-50 & $29.5 \mathrm{a}$ & 24.0ab & $22.6 b$ & $\mathbf{1 7 . 8 b}$ & 1.8ab & $1.6 b$ & $0.9 a$ & $0.9 \mathrm{~b}$ \\
\hline $50-75$ & $16.4 a$ & $14.8 \mathrm{a}$ & 15.1a & $12.6 a$ & 0.8ab & $0.8 \mathbf{a}$ & $0.8 a b$ & $0.4 \mathrm{~b}$ \\
\hline $75-100$ & 11.7a & 11.7a & $10.5 \mathbf{a}$ & $10.9 a$ & $0.4 a$ & $0.4 a$ & $0.2 \mathrm{ab}$ & $0.2 \mathrm{ab}$ \\
\hline Profile (0-100) cm) & $150.5 a$ & 133.8ab & 128.6ab & $107.8 b$ & $9.8 \mathbf{a}$ & $8.9 a$ & 7.5ab & $6.1 b$ \\
\hline
\end{tabular}

Tillage treatments that are followed by the same letters within depth intervals are not significantly different at $P=0.05$.

NT = continuous no-till; ST-NT = short-term no-till; STI-CP = intermittent chisel plow; and CP $=$ continuous chisel plow. 
Our results clearly showed that $24 \mathrm{yr}$ of NT resulted in higher $\mathrm{C}$ and $\mathrm{N}$ content than $24 \mathrm{yr}$ of $\mathrm{CP}$ on an equivalent soil mass basis $\left(43 \mathrm{Mg} \mathrm{ha}^{-1}\right.$ more organic $\mathrm{C}$ and $3.7 \mathrm{Mg} \mathrm{ha}^{-1}$ more total $\mathrm{N}$ ). In that respect, the long-term NT advantage was consistent with the results of McConkey et al. (2003), Duiker and Lal (1999), and Wander et al. (1998). However, ST-NT (17 yr of moldboard plow, $1 \mathrm{yr}$ in chisel $+6-7 \mathrm{yr}$ in no-till) also resulted in a similar organic $\mathrm{C}$ storage as $24 \mathrm{yr}$ of NT. The fact that ST-NT (just 6-7 yr after initiation) resulted in higher soil organic $\mathrm{C}$ and $\mathrm{N}$ concentrations relative to STI-CP and CP treatments was an affirmation that even short-duration no-till may be beneficial to $\mathrm{C}$ accumulation. The small soil $\mathrm{C}$ gained with STI-CP over $\mathrm{CP}$ was attributed to the influence of the previous moldboard plow treatment applied to both intermittent tillage systems. Moldboard plowing frequently turns the residues down to the depth of plowing, while chisel plow distributes residues more evenly throughout at least the upper half of the shank depth to which soil is disturbed. Thus, chisel plowing may cause residues to be more exposed to accelerated soil organic $\mathrm{C}$ oxidization and losses (Paul and Clark, 1996; Curtin et al., 2000; Morris et al., 2004). In fact, Yang and Kay (2000) reported a similar trend where less organic $\mathrm{C}$ was found in the 10 - to $20-\mathrm{cm}$ depth of chisel-plowed than moldboard-plowed soils.

\section{CONCLUSIONS}

The effects of intermittent tillage (ST-NT and chisel) relative to NT and $\mathrm{CP}$ on organic $\mathrm{C}$ and total $\mathrm{N}$ accumulation were studied in CC and SC rotations. Soil C sequestration was not affected by rotation at any depth interval, but rotation had significant effects on $\mathrm{N}$ accumulation at deeper depths $(50-100 \mathrm{~cm})$. Tillage systems significantly altered the content and distribution of $\mathrm{C}$ and $\mathrm{N}$ in the profile. In the surface 0 - to $5-\mathrm{cm}$ interval, organic $\mathrm{C}$ and $\mathrm{N}$ accumulation associated with tillage treatments were in the order: NT $>$ ST-NT $>$ STI-CP $>$ CP. Cumulative organic $\mathrm{C}$ (equivalent mass basis) to a 1 -m sampling depth by NT was about $11 \%$ more than in ST-NT, $15 \%$ more than STI-CP, and $28 \%$ more than CP. After $17 \mathrm{yr}$ of moldboard plow, the establishment of ST-NT and STI-CP systems resulted in soil C mass about 26 and $21 \mathrm{Mg} \mathrm{ha}^{-1}$, respectively, more than that in the continuous CP treatment. This suggested that long-term chisel plowing could be more detrimental and result in greater loss of soil $\mathrm{C}$ than either STI-CP or no-till imposed after moldboard plowing. Short-term intermittent chisel plow (i.e., STI-CP) systems were not significantly different in either C or N storage from NT or $\mathrm{CP}$, but more data are needed to evaluate long-term intermittent tillage effects on organic $\mathrm{C}$ sequestration and soil quality.

\section{REFERENCES}

Allmaras, R.R., H.H. Schomberg, C.L.J. Douglas, and T.H. Dao. 2000. Soil organic carbon sequestration potential of adopting conservation tillage in U.S. croplands. J. Soil Water Conserv. 55:365-373.

Balesdent, J., A. Mariotti, and D. Boisgontier. 1990. Effect of tillage on soil organic carbon mineralization estimated from $13 \mathrm{C}$ abundance in maize fields. J. Soil Sci. 41:587-596.

Barber, S.A. 1979. Corn residue management and soil organic matter. Agron. J. 71:625-627.

Chen, Y., S. Tessier, and J. Rouffignat. 1998. Soil bulk density estimation for tillage systems and soil textures. Trans. ASAE 41: 1601-1610.

Campbell, C.A., B.G. McConkey, R.P. Zentner, F.B. Dyck, F. Selles, and D. Curtin. 1996. Long-term effects of tillage and crop rotations on soil organic $\mathrm{C}$ and total $\mathrm{N}$ in a clay soil in southwestern Saskatchewan. Can. J. Soil Sci. 76:395-401.

CTIC. 2004. National crop residue management survey: A survey of tillage system usage by crops and acres planted. Conservation Technology Information Center, West Lafayette, IN.

Curtin, D., H. Wang, F. Selles, B.G. McConkey, and C.A. Campbell. 2000. Tillage effects on carbon fluxes in continuous wheat and fallow-wheat rotations. Soil Sci. Soc. Am. J. 64:2080-2086.

Diaz-Zorita, M., J.H. Grove, L. Murdock, J. Herbeck, and E. Perfect. 2004. Soil structure disturbance effects on crop yields and soil properties in a no-till production system. Agron. J. 96:1651-1659.

Dick, W.A., R.J. Roseberg, E.L. McCoy, W.M. Edwards, and F. Haghiri. 1989. Surface hydraulic response of soils to no-tillage. Soil Sci. Soc. Am. J. 53:1520-1526.

Dick, W.A. 1983. Organic carbon, nitrogen, and phosphorus concentrations and $\mathrm{pH}$ in soil profiles as affected by tillage intensity. Soil Sci. Soc. Am. J. 47:102-107.

Diekow, J., J. Mielniczuk, H. Knicker, C. Bayer, D.P. Dick, and I. Kongel-Knabner. 2004. Soil C and N stocks as affected by cropping systems and nitrogen fertilization in a southern Brazil Acrisol managed under no-tillage for 17 years. Soil Tillage Res. 81:87-95.

Duiker, S.W., and R. Lal. 1999. Crop residue effects on carbon sequestration in a luvisol of central Ohio. Soil Tillage Res. 52:73-81.

Eghball, B., L.N. Mielke, D.L. McCallister, and J.W. Doran. 1994. Distribution of organic carbon and inorganic nitrogen in a soil under various tillage and crop sequences. J. Soil Water Conserv. 49: 201-205.

Ellert, B.H., and J.R. Bettany. 1995. Calculation of organic matter and nutrients stored in soils under contrasting management regimes. Can. J. Soil Sci. 75:529-538.

Ellert, B.H., H.H. Janzen, and T. Entz. 2002. Assessment of a method to measure temporal change in soil carbon storage. Soil Sci. Soc. Am. J. 66:1687-1695.

Hill, P.R. 1998. Use of rotational tillage for corn and soybean production in the eastern Corn Belt. J. Prod. Agric. 11:125-128.

Hooker, B.A., T.F. Morris, R. Peters, and Z.G. Cardon. 2005. Longterm effects of tillage and corn stalk return on soil carbon dynamics. Soil Sci. Soc. Am. J. 65:188-196.

Karlen, D.L., N.C. Wollenhaupt, D.C. Erbach, E.C. Barry, J.B. Swan, N.S. Nash, and J.L. Jordahl. 1994. Long term tillage effects on soil quality. Soil Tillage Res. 32:313-327.

Kettler, T.A., D.J. Lyon, J.W. Doran, W.L. Powers, and W.W. Stroup. 2000. Soil quality assessment after weed-control tillage in a no-till wheat-fallow cropping system. Soil Sci. Soc. Am. J. 64:339-346.

Lal, R., A.A. Mahboubi, and N.R. Fausey. 1994. Long-term tillage and rotation effects on properties of a central Ohio soil. Soil Sci. Soc. Am. J. 58:517-522.

Mahboubi, A.A., and R. Lal. 1998. Long-term tillage effects on changes in structural properties of two soils in central Ohio. Soil Tillage Res. 45:107-118.

Mahboubi, A.A., R. Lal, and R. Faussey. 1993. Twenty-eight years of tillage effects on two soils in Ohio. Soil Sci. 57:506-512.

McCarty, G.W., N.N. Lyssenko, and J.L. Starr. 1998. Short-term changes in soil carbon and nitrogen pools during tillage management transition. Soil Sci. Soc. Am. J. 62:1564-1571.

McConkey, B.G., B.C. Liang, C.A. Campbell, D. Curtin, A. Moulin, S.A. Brandt, and G.P. Lafond. 2003. Crop rotation and tillage impact on carbon sequestration in Canadian prairie soils. Soil Tillage Res. 74:81-90.

Mehlich, A. 1984. Mehlich 3 soil test extractant: A modification of Mehlich 2 extractant. Commun. Soil Sci. Plant Anal. 15:1409-1416.

Mikhailova, E.A., R.B. Brant, I.I. Vassenev, S.J. Schwager, and C.J. Post. 2000. Cultivation effects on soil carbon and nitrogen contents at depth in the Russian chernozem. Soil Sci. Soc. Am. J. 64:738-745. Morris, D.R., R.A. Gilbert, D.C. Reicosky, and R.W. Gesch. 2004. 
Oxidation potentials of soil organic matter in histosols under different tillage methods. Soil Sci. Soc. Am. J. 68:817-827.

Paul, E.A., and F.E. Clark. 1996. Soil microbiology and biochemistry. Academic Press, San Diego, CA.

Pierce, F.J., M.C. Fortin, and M.J. Staton. 1994. Intermittent plowing effects on soil properties in a no-till farming system. Soil Sci. Soc. Am. J. 58:1782-1787.

Potter, K.N., O.R. Jones, H.A. Torbert, and P.W. Unger. 1997. Crop rotation and tillage effects on organic carbon sequestration in the semiarid southern Great Plains. Soil Sci. 162:140-147.

Potter, K.N., H.A. Torbert, O.R. Jones, J.E. Matocha, J.E. Morrison, Jr., and P.W. Unger. 1998. Distribution and amount of soil organic C in long-term management systems in Texas. Soil Tillage Res. 47: 309-321.

Powlson, D.S., and D.S. Jenkinson. 1981. A comparison of the organic matter, biomass, adenosine triphosphate and mineralizable nitrogen contents of ploughed and direct-drilled soils. J. Agric. Sci. 97:713-721.

Raimbault, B.A., and T.J. Vyn. 1991. Corn rotation and tillage effects on corn growth and soil structural stability. Agron. J. 83:979-985.

Reicosky, D.C. 1997. Tillage-induced $\mathrm{CO}_{2}$ emission from soil. Nutr. Cycling Agroecosyst. 49:273-285.

Reicosky, D.C., W.A. Dugas, and H.A. Torbert. 1997. Tillage-induced carbon dioxide loss from different cropping systems. Soil Tillage Res. 41:105-118.

SAS Institute. 2002. The SAS system for Microsoft Windows. Release 8.2. SAS Inst., Cary, NC.

Schreiber, M.M. 1992. Influence of tillage, crop rotation, and weed management on giant foxtail population dynamics and corn yield. Weed Sci. 40:645-653.

Swift, R.S. 2001. Sequestration of carbon by soil. Soil Sci. 166:835-858.
Unger, P.W., and O.R. Jones. 1994. Infiltration of simulated rainfall: Dry aggregate size effects. J. Agron. Crop Sci. 173:100-105.

VandenBygaart, A.J., and B.D. Kay. 2004. Persistence of soil organic carbon after plowing a long-term no-till field in Southern Ontario, Canada. Soil Sci. Soc. Am. J. 68:1394-1402.

VandenBygaart, A.J., X.M. Yang, B.D. Kay, and J.D. Aspinall. 2002. Variability in carbon sequestration potential in no-till soil landscapes of southern Ontario. Soil Tillage Res. 65:231-241.

Vitosh, M.L., J.W. Johnson, and D.B. Mengel. 1995. Tri-state fertilizer recommendations for corn, soybeans, wheat, and alfalfa. Ext. Bull. E-2567. Michigan State Univ., East Lansing, MI.

Wander, M.M., M.G. Bidart, and S. Aref. 1998. Tillage impacts on depth distribution of total and particulate organic matter in three Illinois soils. Soil Sci. Soc. Am. J. 62:1704-1711.

West, T.D., D.R. Griffith, G.C. Steinhardt, E.J. Kladivko, and S.D. Parsons. 1996. Effect of tillage and rotation on agronomic performance of corn and soybean: Twenty-year study on dark silty clay loam soil. J. Prod. Agric. 9:241-248.

Wilhelm, W.W., and C.S. Wortmann. 2004. Tillage and rotation interactions for corn and soybean grain yield as affected by precipitation and air temperature. Agron. J. 96:425-432.

Yang, X.M., and B.D. Kay. 2000. Rotation and tillage effects on soil organic carbon sequestration in a Typic Hapludalf in Southern Ontario. Soil Tillage Res. 59:107-114.

Yin, X., and M.M. Al-Kaisi. 2004. Intermittent response of soybean yields and economic returns to long-term no-tillage. Agron. J. 96: 723-733.

Zan, C.S., J.W. Fyles, P. Girouard, and R.A. Samson. 2001. Carbon sequestration in perennial bioenergy, annual corn and uncultivated systems in southern Quebec. Agric. Ecosyst. Environ. 86:135-144. 